\title{
THE REGIONAL EXPANSION POLICIES AND CONFLICT RESOLUTION OF BUREAUCRATIC ADMINISTRATION IN INDONESIA'S EXPANSION REGIONS
}

\author{
Suraji \\ Lecturer of Hangtuah University Surabaya Indonesia \& \\ $\mathrm{PhD}$ Student of Ghazali Shafie Graduate School of Government \\ Universiti Utara Malaysia \\ E-mail:surajimunawir@gmail.com \\ Muhamad Ali Embi \\ $\mathrm{PhD}$ Professor of College of Law, Government and International Studies \\ Universiti Utara Malaysia \\ E-mail: ali@uum.edu.my
}

\begin{abstract}
The main subject of the regional expansion basic implementation in the era of regional autonomy is to improve and increase the public services quality to the people of Indonesia. Based on that main subject, initiated actions to implement regional expansion process in Indonesia. The primary objectives of regional expansion include: First, to increase the efficiency and orderliness of the regional government due to Indonesia's wide territory and dense population. Second, Indonesians have a diversity in ethnicity, language, income, and tangible gap between urban and village population. Third, the regions will have three main sources of income under the regional expansions, including general fund allocation provided by the government as regulated by the Act of General Public Fund (DAU - Dana Alokasi Umum), natural resources, and resources of locallygenerated revenue. Fourth, in order to eradicate the symptoms of corruption among interested parties who tend to exploit the central assistance to the regions. In the implementation of new governance and distribution of basic bureaucracy of departmental position and the determination of the sources of the equipment referring to the Act No.32 of 2014 regarding Regional Government, Regional Regulation (PP) No. 78 of 2007 regarding the Procedure of Establishment, Elimination, and Merging of Regions, and Act No. 5 of 2014 regarding State Civil Administration. This basis has become a reference in regional expansion and the determination of regional equipment which comprises of the principles of efficiency, feasibility, sincerity of achievement, and objectivity free of political interests, corruption, collusion, and nepotism. This study is expected to reveal the problems and the right solutions in the issue of regional expansion and to contribute to the academia specifically in the field of public policy, specifically related to regional autonomy.
\end{abstract}

Keywords: Regional Expansion, Conflict of Interest, Public Bureaucracy 


\section{Introduction}

After the implementation of regional expansion in 1999 to 2014, it is known that there are many regions which have had a regional expansion. It is an authority of the central government, which is a regional public initiative and implemented by the regional government. However, in its implementation, it did not align with the basic objectives of regional expansion. Therefore, problems occurred during the expansion which hampered the regional development.

In its development, to date, almost $100 \%$ of regional expansion have been implemented throughout Indonesia's regions, becoming regional government and District/City autonomous region which conducts the governance. However, the regional expansion policies since Joko Widodo-Jusuf Kalla administration in 2014 encountered a moratorium policy which terminates the proposal of new expansion regions. Joko WIdodo-Jusuf Kalla government firmly denies proposals of new expansion regions, even though there were regions which requested for an expansion

The development of regional expansion in Indonesia can be seen in the following Table:

Table

Regional Expansion Development in Indonesia in 1999-2019

\begin{tabular}{lcc}
\hline Region/District/City & $\begin{array}{c}\text { Expansion Regions } \\
\mathbf{1 9 9 9 - 2 0 1 4}\end{array}$ & $\begin{array}{c}\text { Demands of Expansion } \\
\text { Regions 2014-2019 }\end{array}$ \\
\hline Province & 34 & 4 \\
District & 420 & 176 \\
City & 94 & 15 \\
& 548 & 195 \\
\hline
\end{tabular}

Source: Ministry of Home Affairs of Republic of Indonesia, 2019

After the regional expansion is implemented, many researches conclude that the implementation failed in terms of public services, welfare, and good governance implementation. This was due to the implementation that had not yet fulfilled the dedication to public. The regional expansion was conducted without a proper planning, there was a religious, ethnic, and subjective interests without any sign of equal authority and pursuit of public office position (Sudi Fahmi, 2009; Prasojo, 2014).

According to Eko Prasojo (2014), the issue of regional expansions is not only about political interests of regional officials who want to take roles and pursuit office position, but due to the inconsistent management of Centerwork toward the new expansion regions regarding the expansion goals, either in the expansion procedure, construction, or in the human resources development in the new expansion regions. The facts show that the basic of regional expansion almost in all region of Indonesia is inseparable from conflicts rooted from the initial conditions of expansion, expansion process, post-expansion, or becoming autonomous region, and from the implementation of bureaucratic management. As depicted in the following table: 
Page 554-570. ISBN: 978-602-6 988-75-1

Web Jurnal Online: jurnal.unmuhjember.ac.id

By: Suraji; Muhammad Ali Embi

The Regional Expansion Policies and Conflict Resolution of Bureaucratic Administration

In Indonesia's Expansion Regions

Table

Conflict of Regional Expansion Process in Indonesia

\begin{tabular}{|c|c|c|c|}
\hline Region & Main District & New District & Conflict \\
\hline $\begin{array}{l}\text { Kalimantan } \\
\text { Barat }\end{array}$ & Bulungan District & $\begin{array}{l}\text { Kalimantan Utara } \\
\text { (1999) }\end{array}$ & $\begin{array}{l}\text { Dispute on regional assets and transfer of } \\
\text { regional officials }\end{array}$ \\
\hline $\begin{array}{l}\text { Kalimantan } \\
\text { Utara }\end{array}$ & Bengkayang District & $\begin{array}{l}\text { Sengkawang City } \\
(2000)\end{array}$ & $\begin{array}{l}\text { Migration conflicts and civil servants moved } \\
\text { to Sengkawang City }\end{array}$ \\
\hline Aceh & Lhoksumawe District & $\begin{array}{l}\text { Lhoksumawe City } \\
\text { (2001) }\end{array}$ & $\begin{array}{l}\text { Employment issues and public civil servants } \\
\text { preferred Lhoksumawe City }\end{array}$ \\
\hline Papua Barat & Manukwari District & $\begin{array}{l}\text { Manukwari Selatan } \\
\text { District (2002) }\end{array}$ & $\begin{array}{l}\text { Pros cons on expansion, dispute over } \\
\text { Regional Government office, civil public } \\
\text { servant mutation issue }\end{array}$ \\
\hline Riau & Kepulauan Riau & $\begin{array}{l}\text { Tanjung Pinang } \\
\text { (2003) }\end{array}$ & $\begin{array}{l}\text { Dispute over regional assets including Civil } \\
\text { Servants resources }\end{array}$ \\
\hline Sumatra Utara & Batu Barat District & $\begin{array}{l}\text { Riang District } \\
(2004)\end{array}$ & Pros and cons of the Capital of the Province \\
\hline $\begin{array}{l}\text { Nusa Tenggara } \\
\text { Barat }\end{array}$ & Sumbawa District & $\begin{array}{l}\text { Sumbawa City } \\
(2005)\end{array}$ & Dispute over quality public civil servants \\
\hline $\begin{array}{l}\text { Sumatra } \\
\text { Selatan }\end{array}$ & Tapanuli District & $\begin{array}{l}\text { Tapanuli City } \\
\text { (2006) }\end{array}$ & $\begin{array}{l}\text { Dispute over the Capital of the Province } \\
\text { Pros and cons on expansion and dispute over }\end{array}$ \\
\hline & Kampar District & $\begin{array}{l}\text { Kampar City } \\
\text { (2007) }\end{array}$ & regional border \\
\hline Sumatra Utara & Ogan Hilir District & $\begin{array}{l}\text { Ogan Komering } \\
\text { Hilir District } \\
\text { (2008) }\end{array}$ & $\begin{array}{l}\text { Conflictive dispute over the number of } \\
\text { districts }\end{array}$ \\
\hline $\begin{array}{l}\text { Sulawesi } \\
\text { Tenggara }\end{array}$ & Konawe District & $\begin{array}{l}\text { Konawe City } \\
(2009)\end{array}$ & Dispute over village and district areas \\
\hline $\begin{array}{l}\text { Kepulauan } \\
\text { Riau }\end{array}$ & Natuna District & $\begin{array}{l}\text { Anambas District } \\
(2010)\end{array}$ & $\begin{array}{l}\text { Dispute over natural resources and district } \\
\text { border }\end{array}$ \\
\hline $\begin{array}{l}\text { Kalimantan } \\
\text { Selatan }\end{array}$ & $\begin{array}{l}\text { Hulu Sungai Utara } \\
\text { District }\end{array}$ & $\begin{array}{l}\text { Balangan District } \\
\text { (2011) }\end{array}$ & $\begin{array}{l}\text { Dispute over regional assets in forms of } \\
\text { buildings, infrastructures, and arrangement } \\
\text { of position in family manner of Regent }\end{array}$ \\
\hline Jawa Barat & Ciamis District & Banjar City (2012) & $\begin{array}{l}\text { Dispute over district border and district } \\
\text { offices }\end{array}$ \\
\hline $\begin{array}{l}\text { Nusa Tenggara } \\
\text { Timur }\end{array}$ & Sumba District & $\begin{array}{l}\text { Sumba Barat Daya } \\
\text { District (2013) }\end{array}$ & $\begin{array}{l}\text { Dispute over regional government offices, } \\
\text { airport, and arrangement of Civil Servants } \\
\text { mutation to Sumba Barat Daya }\end{array}$ \\
\hline Jawa Timur & Malang City & $\begin{array}{l}\text { Batu District } \\
\text { (2014) }\end{array}$ & $\begin{array}{l}\text { Dispute over tourist locations, district } \\
\text { offices, and Civil Servants mutation }\end{array}$ \\
\hline
\end{tabular}

Source: Ministry of Home Affairs of Republic of Indonesia, 2018 
In the conflict of expansion interests, there were actors involved directly, such as the Governor as regional authority, Regent officials as the head of expansion region department, Presidium Boards as the initiator of regional expansion proposal, Regional Representative Council (DRPD) as the representative of regional people, NGO as organizations concerned in regional expansion, as well as political parties as political organization oriented to the people.

The conflict of interest in regional expansion that involves actors has interconnected phases, including: the phase of conflict of interest between the Main District Regent and the Presidium Board in the initial process of expansion proposal. The phase of conflict of interest with the Regional Representative Council in the establishment of expansion regulation. The phase of conflict of interest between regent officials and provincial government and Presidium Board. The phase of conflict of interest between the Presidium Board and Regent Officials on the proposal of region of the district Capital city. The phase of conflict of interest between the Regent Officials and Main district Regent in the management of assets, regional border, and the phase of conflict of interest in the arrangement of public civil servants of the main district and the expansion regions. These phases happened, on average, during the process of regional expansion implementation in Indonesia.

These problems require special attention and resolution so that the regional expansion implementation can be finished well, if there is a conflict of interest, it can be quickly anticipated by the authorities, including the Governor, Regent Officials, Presidium Board, Regional Representative Council (DPRD), there is the right regional expansion regulation so that the expansion can be conducted well. The objectives of optimal regional expansion aligns with the objectives of regional development, which are to be developed, prosperous, to improve the level of services, improve the public services, and implement good governance.

\section{Literature Review}

The occurrence of regional expansion idea in almost all region of Indonesia is profound. Several subdistricts in a region have been turned into a region/city that separate itself from the main region/city and there are regions/cities that merged into one new region. According to Garielle Ferrazzi (2007), regional expansion is a process of regional structure, which is a structure within a regional government to achieve a political objective and/or administration. Generally, a regional structure comprises of regional divisions, merging, and eliminations. Therefore, Ferrazzi (2007) argues that regional expansion related to the regional autonomy's optimal grand strategy does not stop on determining the ideal number of autonomous regions in a country, it must be able to state the nature of the involved regional autonomy. Then, after that, it seeks for answers on the objective of the regional expansion.

Kusworo (2001) argues that regional expansion is an implementation of territorial process wherein the government exercises its authority given by a public institution, such as an organization which has its own governance to thoroughly develop interconnected interests between groups of people within a certain region. Regional expansion that is 
synergized with decentralization and regional autonomy is a renewal's will and regional demand. However, the implementation still becomes the unfulfilled agenda and hope. According to Tryatmoko (2010), the issue of regional expansion is not only marked by the weakness or division of regional assets but also the people's weak ability to support the local political and economic development. Furthermore, Tryatmoko argued that the issues of effectiveness of the government in regional expansion related to the effectiveness and legitimation. Therefore, the regional expansion is in relation to the public involvement in the decision-making and supervision of the government. In this case, regional expansion requires special attention, continuous supervision, and gradual assessment.

Miftah (2015) argues that regional expansion is a dynamic revolution entity which is the national government's interest in the Republic of Indonesia. National interest Is a national government's interest that establishes nationalism, national spirit, and embraces regional spirit as a national unifying culture. Therefore, the national interest in regional expansion is conducted through the principle of decentralization from central government to transfer a part of its authority to the regional government. It is supported by Kaloh (2007) that stated the context of regional expansion is better known by new autonomous region establishment. The autonomous regions are expected to be able to take bigger opportunities in governing their own regions, especially in relation to the management of the locally-generated revenue, natural resources, in order to improve prosperity, and better public services.

According to Kaloh (2007), regional expansion is basically an attempt to improve the public service quality and intensity. It is, in principle, also an attempt to increase the social prosperity by improving and fastening the services and supporting democratic politics, regional economy, management of regional potentials, security, and orderliness, as well as the harmonious relationship between the center and regions. Therefore, there are several reasons why regional expansion is currently important, first, the will to provide better public services. The approach of service through a new regional government will give a better service compared to the ones through the main regional government with a wider area of coverage. Through the process of a more limited regional expansion, the more suitable public services to the local demand will be available. Secondly, speed up the economic growth of local people through banking with a framework of regional economic development based on local potentials. By developing new autonomous regions, there will be more chances to explore the regional economic potentials that have not been much explored. Thirdly, a wider labor absorption in government sector and authority distribution in the field of politics and government. In fact, this kind of politics is also widely supported by the people and business industry since it can develop regions as an impression of regional expansion (Herman, 2005, Ferrazi, 2007, Kaloh, 2007).

In the context of bureaucratic arrangement of expansion region, Siagian (1993) argued that human resource management is a part of organization focused on human aspects. The main task of human resource management is to manage the human aspects well so that the employees who are satisfied by the job can be recruited. Therefore, the 
tasks of human resource management can be categorized into two: firstly, functions of management, planning, organization, direction, and control. Secondly, functions of operation, provision, establishment, compensation, integration, maintenance, and work termination.

The conflict of interest in the bureaucratic arrangement in expansion regions begins with in individual and group interests, as well as inappropriate regulation. The sources of regional equipment are imperative as a basis of regional development, either division or autonomous regions. The process of structure and the institution's performance contain interests and conflicts. The weak system of public civil servants in Indonesia is often imbued with a conflict of interest. This happens in almost every human resource management. The process of recruitment, placement, promotion, mutation, development, and assessment are often biased due to the conflict of interest. It is proven by the rising trend of corruption-collusion-nepotism that has proven public work system to be not neutral. The phenomena of civil servants recruitment process and placement, as well as position formation, have become a source of conflict of interest (Sulistiyani, 2010).

\section{Research Method}

\subsection{Data Sources}

Primarily, the data consisted of the results of direct observation at the research location including the reports on regional performance, reports from the Central Bureau of Statistics (BPS) on each Regional Government Agency (SKPD), Ministry of Home Affairs' and Governors' decisions regarding the decisions of the regent, regent's decree $(S K)$ on the determination and arrangement of $S K P D$, decree on echelon regulation, decree on $S K P D$ determination, placement decree of employees, and decree concerning the regional structure.

Meanwhile, the secondary data consisted of the results of direct interviews with some sources of information (participants), which consisted of the Regent, Secretary, Expedition Presidents, and Heads of SKPD, several representatives of relevant officials, Community Leaders, Academicians, NGOs, and citizens. Lastly, the other source of data came from district archives, district conditions before and after the regional division, the district original documents, and other data related to the research problem.

\subsection{Research Scope}

The scope of this study was Pangandaran Regency, West Java Province. Pangandaran was chosen as the study site due to the wide region of Ciamis (Report by Bappeda or Development Planning Agency at Sub-National Level, 2017).

\subsection{Data Collection Method}

Data collection was done by applying semi-structured interviews such as observing community participation (participant observation), reviewing documents based on sources and data types, and conducting field reviews with direct observation regarding the research issues and social interactions. The words were arranged by action while 
comparing written sources (the documents), field notes, maps and statistical data. Furthermore, the data collected would then be processed through the following activities: (1) preparation of units, (2) categorization by determining the categories of the obtained data, and (3) putting the data in their respective categories.

\subsection{Data Analysis Techniques}

The data analysis in this study revealed the data to be discovered, the hypotheses to be tested, the questions to be answered, the methods to be used to find new information, and the errors that should be corrected (Nasution, 1988). Data testing was done by using the triangulation technique, by doing check, recheck, and cross-check to the obtained data (Moleong, 1998:178). The triangulation technique is a data matching procedure through several different sources to obtain the valid data. It could be done on several important aspects of data such as data sources, methods, investigations, and theories. Triangulation that used the sources was done by (1) comparing the research data with the result of the interviews; (2) comparing what people have said in public with what they have said personally; (3) comparing what people say about the research situation with what people say all the time; (4) comparing one's statement and perspective with the opinions and views of others; and (5) comparing the results of interviews with the contents of a related document. The triangulation method was done by synchronizing the first data with the second data, with the third data and so on, and going back to the first data, respectively. Technically, each of these data would be cross-checked with the other data to ensure the accuracy and veracity of the data.

\section{Discussion and Conclusion}

\subsection{Conflict of Interest in the Bureaucratic Arrangement of Expansion regions}

The system of regional institution is an institutional system that shows the relationship and tasks distribution in an organization within an autonomous region. The complexity borne by expansion regions and the number of units within the organizational structure of regional organization, the system of regional institution will be very crucial to the effectiveness of the implementation of tasks, as well as accomplishment of objectives to provide better service to the public. The basis of regional government is a political decision that reflects an organization's interest. Meanwhile, the process is explicitly related to interests, either internal or external interests.

In the dynamics of regional expansion as a new autonomous region, the establishment of regional institution can cause an institutional conflict. The occurrence of conflicts in real institutional establishment can be seen in the making of the institution's Main Tasks and Functions (Tupoksi) in which there are two Regent's Regulations by Presidium Board of Pangandaran District Expansion, such as Regent's Regulation No. 2 of 2013 and No. 3 of 2014 regarding Tupoksi, Work Organization, and Regional Organization. The Pangandaran Regent's Regulation No. 2 of 2013 regarding Tupoksi, Work Organization, and Regional Organization is considered right and suitable to Pangandaran District because it is based on the need of new district, which aligns with the pre-existing needs. However, with the existence of new Regent's Regulation No. 3 of 
2014, it is considered by the Presidium Board very maximum and currently with no explanation.

The conflict in the institution's tupoksi is in fact caused by the occurrence of two Regent's Regulations, which according to Presidium Board, is unclear. Meanwhile, Pangandaran District is still considered incapable of conducting an optimal implementation due to its limited human resources and nonoptimal bureaucracy to operate organizations well according to the tupoksi on Pangandaran Regent's Regulation No. 3 of 2014. Regent's Regulation No. 3 of 2014 is considered implemented hastily and inaccurate. This issue is generally occurs due to the different understandings of the regulation, including the old regulation considered unofficial by the Regent if there is a new regulation. Meanwhile, the Presidium Board considers it the most suitable to be the basis of institutional establishment in Pangandaran District. This is due to the process of drafting and making of the regulation that did not involve the Presidium Board.

The aspects in the conflict of interest within regional institution establishment is structural dimension. The structural dimension of an organization is related to who implements or conducts what was stipulated. The organizational structure of the Government of Pangandaran District has not yet been completely optimizing public services, it requires an optimal organization of SOPD. It can be achieved by following the phases of development happening due to the increase of Civil Servants in Pangandaran District. From the problem, it has been formulated a solution by considering the importance of SOPD, which has not been organized and completed, as well as proposing to the Ministry of Home Affairs through the Governor of West Java.

The organizational structure of the Government of Pangandaran District has not yet been completely optimizing public services, it requires an optimal organization of SOPD. It can be achieved by following the phases of development happening due to the increase of Civil Servants in Pangandaran District. Gradually, there have been attempts to strengthen and fasten the wheel of organization in Pangandaran District. The issue is on the structural organization and personnel who are suitable to their fields and competence, as well as fulfilling the requirements, which needs to be precise.

The elected Regent Officials of Pangandaran automatically receive statutory duties including to provide governmental institution, appoint Head of Departments, form Regional Government Work Units, and organize the Definitive Regent Election. The first step of a Regent Official of Pangandaran, Dr. Endang Naffandy, is to appoint the Head of Department. The initial process of this stipulation is the assessment of ability and administrative requirements. In this process interests and issues occur, started from an issue of friendship and 'internal link' from a main district (Ciamis), as well as suggestions from the presidium board. The conflict became more real when the suggestion of the presidium board to appoint local men or officials who were once on duty when Pangandaran was still a district.

The difference in views between the Regent and Presidium in terms of addition in personnel and stipulation of officials' names and the empty seat of Head of Department of Education, Youth, and Sport have become the meeting point to discuss those issues, which eventually is agreed by fulfilling 5 personnel and candidates of Head of 
Department of Education, Youth, and Sport through election and provision of budget for the following year.

The findings above show that the process of choosing Head of Department, SKPD, and establishment of new unit in the beginning had conflict of interest, as well as responses from the community, especially from Expansion Presidium. From the presidium and regent's suggestion, it is mutually agreed, except regarding the position of the Head of Department of Education, Youth, and Sport which was still empty, there was an interest that the one who will take the position of the Head of Department of Education, Youth, and Sport is from other region (Bandung City).

In the strengthening and development of government in expansion regions, the factor of institution determination factor becomes vital directly in workplace from the organization, changing the mindset regarding the way of thinking, working, and the courage to take new basis, as well as implementing the tasks and responsibilities to the development of expansion regions.

\subsection{Attempts of Solving Conflict of Interest}

In the dynamics of expansion regions as new autonomous institutions, the organization of regional institution can cause conflict of position. The conflict occurs in relation to the interest regarding the stipulation of regional position after becoming a new autonomous region, such as conflict of interest in the establishment and arrangement of number of positions, drafting of main tasks and functions (Tupoksi), arrangement of bureaucratic structure, and organization of regional organization in Pangandaran District. Such issues happened due to the readiness to become an autonomous region or expansion regions were not completely ready politically and technically. Politics here is defined as obedient to the regulation and is committed to the regional development instead of personal and group temporary interests.

Conflict of interest is a situation where individuals who have a difference with the organizational interest, yet their existence is often attached, stuck, or aligned with the organizational interest which they are affiliated with, and take advantages from the policies and management there. The weak system of public employment in Indonesia is often imbued with conflict of interest and this happens almost in all function of human resource management. The process of recruitment, placement, promotion, mutation, development, and evaluation are often biased due to the conflict of interest.

The arrangement process of regional positions in the expansion region of Pangandaran District is inseparable from a conflict of interest. It happens on the strategic positions and the attempts of strengthening either from the position, regional potentials, and resources within Pangandaran District with the public figures who are not satisfied contributed to the conflict in the expansion management of Pangandaran District. As the rules on position created by the Regional Government of Pangandaran District, which considered double including Regent's Regulation No. 2 of 2013 and No. 3 of 2014 regarding the main tasks and functions (Tupoksi), Work Organization, and Regional Work Organization, issues of Regent's performance, the arrangement Regional 
Page 554-570. ISBN: 978-602-6 988-75-1

Web Jurnal Online: jurnal.unmuhjember.ac.id

By: Suraji; Muhammad Ali Embi

The Regional Expansion Policies and Conflict Resolution of Bureaucratic Administration

In Indonesia's Expansion Regions

Organizational Unit, the number of districts from 14 to 10 and the stipulation of the Capital city of Pangandaran.

In the implementation, the actors regarding the regional position which triggered a conflict of interest was the unsatisfaction of presidium board of Pangandaran expansion, NGO, public figures, and elites of bureaucracy. This was due to the difference in perspectives and miscommunication, as well as the role of the Regent in managing and implementing Regional Government that is still considered not optimal. Besides, in the appointment of personnel that will fully take the position with the interest of elites of bureaucracy, political party, and regional elites.

Even though there was a conflict of interest during the process of position arrangement in the management of government and regional policies in Pangandaran District, generally it went well and the conflicts can be solved gradually by involving all element of Pangandaran District. In order to actualize the objectives of regional expansion, it vitally requires a constant supervision and management in accordance with the principles of good, aspirational governance, which is cooperative to local institutions to develop the autonomous region to be a developed and prosperous region, suitable to the initial needs. Pangandaran District was expanded. The attempts to solve conflict of interest in the position can be seen in the following table:

Table

Attempts of Solving Conflict of Interest

Bureaucratic Arrangement in Expansion Regions

\begin{tabular}{|c|c|c|c|c|}
\hline $\begin{array}{l}\text { Conflict } \\
\text { Actors }\end{array}$ & $\begin{array}{l}\text { Conflict } \\
\text { interests }\end{array}$ & $\begin{array}{l}\text { Beginning of } \\
\text { conflict }\end{array}$ & nics & ution \\
\hline $\begin{array}{l}\text { Governo, } \\
\text { Political } \\
\text { Parties, } \\
\text { Presidium } \\
\text { Board }\end{array}$ & $\begin{array}{l}\text { Position of } \\
\text { Regent }\end{array}$ & $\begin{array}{l}\text { After } \\
\text { Pangandaran } \\
\text { officially } \\
\text { became a } \\
\text { new district, } \\
\text { then it needs } \\
\text { to be } \\
\text { appointed a } \\
\text { district } \\
\text { leader, which } \\
\text { is a regent. In } \\
\text { this case, } \\
\text { there were } \\
\text { three groups } \\
\text { who } \\
\text { proposed } \\
\text { candidates } \\
\text { for the } \\
\text { position, }\end{array}$ & $\begin{array}{l}\text { There was a } \\
\text { conflict especially } \\
\text { on the people of } \\
\text { Pangandaran, } \\
\text { asking presidium to } \\
\text { press and protest if } \\
\text { the suggestion of } \\
\text { candidates to the } \\
\text { regent position are } \\
\text { not the one desired } \\
\text { by the community, } \\
\text { which is regional } \\
\text { people. Meanwhile, } \\
\text { the authority } \\
\text { belongs to the } \\
\text { Governor to } \\
\text { appoint it to the } \\
\text { Ministry of Home } \\
\text { Affairs }\end{array}$ & $\begin{array}{l}\text { After the decision that } \\
\text { the elected regent } \\
\text { official was Endang } \\
\text { Naffandy, which } \\
\text { officially designated on } \\
22 \text { April 2013, the } \\
\text { conflict became stronger } \\
\text { and resulted in } \\
\text { presidium and people's } \\
\text { disappointment. Endang } \\
\text { Naffandy, on daily } \\
\text { basis, is assigned to be } \\
\text { expert staff of the } \\
\text { Governor of Jawa Barat. } \\
\text { Because it is not suitable } \\
\text { to what was desired, } \\
\text { then the conflict } \\
\text { resolution only accepts } \\
\text { as regent official in }\end{array}$ \\
\hline
\end{tabular}


Proceeding ICOGISS 2019

Page 554-570. ISBN: 978-602-6 988-75-1

Web Jurnal Online: jurnal.unmuhjember.ac.id

By: Suraji; Muhammad Ali Embi

The Regional Expansion Policies and Conflict Resolution of Bureaucratic Administration

In Indonesia's Expansion Regions

\begin{tabular}{|c|c|c|c|c|}
\hline & & $\begin{array}{l}\text { which were } \\
\text { Bureaucracy } \\
\text { (Governor). } \\
\text { Political } \\
\text { Parties, and } \\
\text { Presidium } \\
\text { Board. }\end{array}$ & & Pangandaran. \\
\hline $\begin{array}{l}\text { Presidium } \\
\text { Board }\end{array}$ & $\begin{array}{l}\text { Position of } \\
\text { Regional } \\
\text { Secretary }\end{array}$ & $\begin{array}{l}\text { The position } \\
\text { of regional } \\
\text { secretary had } \\
\text { been empty } \\
\text { for } 9 \text { months. } \\
\text { The } \\
\text { Presidium } \\
\text { Board } \\
\text { suggested to } \\
\text { immediately } \\
\text { fill it. The } \\
\text { conflict arose } \\
\text { when the } \\
\text { regent } \\
\text { official did } \\
\text { not } \\
\text { immediately } \\
\text { appoint } \\
\text { Makmud } \\
\text { who was } \\
\text { proposed by } \\
\text { the } \\
\text { Presidium } \\
\text { Board } \\
\text { because he is } \\
\text { a regional } \\
\text { person and } \\
\text { have a } \\
\text { competence. }\end{array}$ & 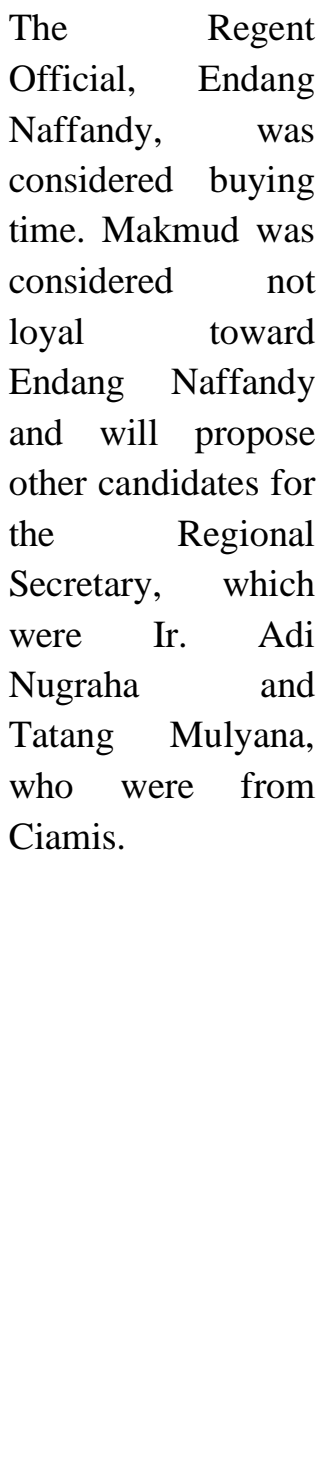 & $\begin{array}{l}\text { Because of Endang } \\
\text { Naffandy's slow } \\
\text { response, there was an } \\
\text { objection and } \\
\text { demonstration. Because } \\
\text { of the condition of } \\
\text { Pangandaran that } \\
\text { became more } \\
\text { uncomfortable, then the } \\
\text { Regent Official Endang } \\
\text { Naffandy appointed } \\
\text { Makmud as the } \\
\text { Regional Secretary. The } \\
\text { conflict was resolved } \\
\text { because it was suitable } \\
\text { to the aspiration of the } \\
\text { Presidium Board, even } \\
\text { though it had to wait for } \\
\text { quite a long time, } 9 \\
\text { months. }\end{array}$ \\
\hline $\begin{array}{l}\text { Presidium } \\
\text { Board }\end{array}$ & $\begin{array}{l}\text { Position of } \\
\text { Head of } \\
\text { Departmen } \\
t \quad \text { of } \\
\text { Regional } \\
\text { Governme } \\
\text { nt Agency }\end{array}$ & $\begin{array}{l}\text { The process } \\
\text { of } \\
\text { appointment } \\
\text { of Head of } \\
\text { Department } \\
\text { of Regional } \\
\text { Government }\end{array}$ & $\begin{array}{l}\text { There was no } \\
\text { concern and } \\
\text { inconveniences in } \\
\text { the internal of } \\
\text { regional } \\
\text { government and } \\
\text { community. }\end{array}$ & $\begin{array}{l}\text { Granting a role to the } \\
\text { Presidium Board to } \\
\text { propose proper and } \\
\text { qualified candidates. } \\
\text { Furthermore, the Regent } \\
\text { Official Endang formed } \\
\text { a team. This team }\end{array}$ \\
\hline
\end{tabular}


Proceeding ICOGISS 2019

Page 554-570. ISBN: 978-602-6 988-75-1

Web Jurnal Online: jurnal.unmuhjember.ac.id

By: Suraji; Muhammad Ali Embi

The Regional Expansion Policies and Conflict Resolution of Bureaucratic Administration

In Indonesia's Expansion Regions

\begin{tabular}{|c|c|c|c|c|}
\hline & (SKPD) & $\begin{array}{l}\text { Agency was } \\
\text { considered } \\
\text { imbued with } \\
\text { interest } \\
\text { because it } \\
\text { consisted of } \\
\text { names of } \\
\text { officials } \\
\text { from other } \\
\text { districts, } \\
\text { colleagues, } \\
\text { and relatives. }\end{array}$ & & $\begin{array}{l}\text { involved the Presidium } \\
\text { Board for the selection } \\
\text { process of the potential } \\
\text { Head of Department }\end{array}$ \\
\hline $\begin{array}{l}\text { Panganda } \\
\text { ran } \\
\text { Regent } \\
\text { Officials } \\
\text { and } \\
\text { Regent of } \\
\text { Ciamis }\end{array}$ & $\begin{array}{l}\text { Employees } \\
\text { Placement }\end{array}$ & $\begin{array}{l}\text { Addition of } \\
\text { employees } \\
\text { from the } \\
\text { main district } \\
\text { (Ciamis } \\
\text { District) }\end{array}$ & $\begin{array}{l}\text { In the placement, } \\
\text { there were some } \\
\text { issues due to the } \\
\text { questionnaire and } \\
\text { issue of regional } \\
\text { person. Other than } \\
\text { the ones transferred } \\
\text { voluntarily and } \\
\text { involuntarily. BKD } \\
\text { of Ciamis District } \\
\text { randomly appointed } \\
\text { without any } \\
\text { consent. Therefore, } \\
\text { it affected the } \\
\text { performance where } \\
\text { the employees who } \\
\text { were originally } \\
\text { from CIamis were } \\
\text { placed in } \\
\text { Pangandaran, } \\
\text { which is } \\
\text { geographically far } \\
\text { from home. }\end{array}$ & $\begin{array}{l}\text { The resolution to this } \\
\text { conflict involved the } \\
\text { Governor and Regional } \\
\text { BKD and the respective } \\
\text { BKD of Pangandaran } \\
\text { and Ciamis, which were } \\
\text { to re-examine the } \\
\text { employee placement in } \\
\text { Pangandaran District. }\end{array}$ \\
\hline $\begin{array}{l}\text { Regional } \\
\text { Secretary }\end{array}$ & $\begin{array}{l}\text { The } \\
\text { incompatib } \\
\text { ility in the } \\
\text { performan } \\
\text { ce since } \\
\text { Regional } \\
\text { Secretary } \\
\text { Makmud }\end{array}$ & $\begin{array}{l}\text { The Regional } \\
\text { Secretary } \\
\text { was } \\
\text { considered } \\
\text { by the } \\
\text { Regent close } \\
\text { to the } \\
\text { presidium. }\end{array}$ & $\begin{array}{l}\text { The disharmony } \\
\text { between the Regent } \\
\text { and Regional } \\
\text { Secretary made the } \\
\text { institutional } \\
\text { relationship and } \\
\text { bureaucratic } \\
\text { coordination }\end{array}$ & $\begin{array}{l}\text { The resolution between } \\
\text { the Regional Secretary } \\
\text { and Regent was } \\
\text { facilitated by the } \\
\text { Regional Government. }\end{array}$ \\
\hline
\end{tabular}


Proceeding ICOGISS 2019

Page 554-570. ISBN: 978-602-6 988-75-1

Web Jurnal Online: jurnal.unmuhjember.ac.id

By: Suraji; Muhammad Ali Embi

The Regional Expansion Policies and Conflict Resolution of Bureaucratic Administration

In Indonesia's Expansion Regions

was

appointed. disrupted. Besides,

it impacted the pros

and cons in the

bureaucracy of

Regional

Government of

Pangandaran

District.

Regent Position of The

Made the Head of A collective meeting to

Official

Head of suggestion of

Departmen expansion by

$\mathrm{t}$

of the

Education, Presidium

Youth, and was not

Sports.

Department

of discuss the candidates

Education empty. for Position of Head of Department of Education, Youth, and Sports through a selection.

ed.

Source: Collected from the research findings 2018 


\section{Implication}

In the strengthening and development of the government in expansion regions, institutional dimension and human resources become the determining factor of a region's success. Institutional aspects and human resources are interesting to be studied as a focus of this study, viewing regional expansion from the potentials of human resources and institution in preparing and implementing the governance after regional expansion. The determining factor of institutions and strategic position of regional personnel are more into the direct utilization at workplace from the organization, changing mindset in the way of thinking, working, and the courage to take new basis, as well as implementing the tasks and responsibilities to the development of expansion regions.

The personnel's professionalism consists of three important values that must be developed. Firstly, the tasks and roles must be oriented to public interest. Secondly, the personnel's professionalism must be based on education and rationality instead of patriotic. Thirdly, hold firmly the principle of 'the right man on the right place'. The personnel's professionalism with a nationality values is required to cope with the difficult situation compared from the past, the fast development of technology, major change in the level of education, and transformation of work value, then the characteristics and tasks of bureaucracy are also changed. The tasks in bureaucracy will be more technical, difficult, and not programmed deeply (Miftah Thoha, 1992).

The existence of conflict of interest in the establishment of institutional arrangement and apparatus placement in expansion regions. In this case, the conflict is related to the organization's attempts to develop the organization and utilizing the regional personnel for expansion regions. The governmental bureaucracy is an institution that is able to give a political role in solving conflicts occurred between individuals and groups. The relationship between political institutions, elites, public figures, and bureaucracy as a conflict of interest where the bureaucracy is a party that will govern information. Accordingly, the flow of information becomes asymmetrical. This fact becomes the source of bureaucratic negotiation when interacting with political institutions. The conflict of interest in the establishment of institution and placement of regional personnel human resources will strengthen the institution if it can be handled well in accordance with the regulation, using a thorough approach. Then, the establishment of institution and placement of regional personnel human resources in the expansion regions will be the best solution, therefore it will not continue to other conflict. This kind of case requires a strategic, synergized, and focused basis in handling and managing expansion regions. 
Proceeding ICOGISS 2019

Page 554-570. ISBN: 978-602-6 988-75-1

Web Jurnal Online: jurnal.unmuhjember.ac.id

By: Suraji; Muhammad Ali Embi

The Regional Expansion Policies and Conflict Resolution of Bureaucratic Administration

In Indonesia's Expansion Regions

\section{References}

B Daniel J. Elazar (1995), Performance Measurement and Management in Bouckeart, K.and Verschuere.

Cheema, Shabbir and Dennis Rondinelli. (1983). Decentralization and Development, Bevely, CA, Sage Publications.

Carpenter, L.Susan, WJD.Kennedy, (1988), Managing Publik Dispute, Jossey-Bass Publishers, Sanfransisco, Landon.

Elazar, Daniel J, (1995) "Federalism", in Afan Gafar, et al., Ed. II, 1995, "Regional Autonomy within the Unitary State", Pustaka Pelajar, Yogyakarta.

Fahmi, Sudi, (2009). Law of Regional Autonomy, Total Media, Yogyakarta.

Farazmand, Ali, 2001, Handbook af Comperative and Development Public Administration, Socond Edition, Revised and Expanded, Marcel Dekker, Inc, New York Basel.

Ferrazzi, Gabriele, (2007). International Experiences in Territorial Reform-Implications For Indonesia, Jakarta USAID-DRSP, January p. 7

Fitriani, (2005), Unity in Diversity? The Creation of New Local Governments in A Decentralizing of Indonesian Economic Staudies, Vol 41. No.1.

Grindlle, M.S., (editor), (1997). Getting Good Government: Capacity Building in The Public Sector of Developing Countries, Boston, MA: Harvard Institute for International Development.

Keban, Yeremias T, (2000). Basic Concept of Capacity Building Program, National Development Planning Magazine, Jakarta.

Kosworo, E., (2001). Regional Autonomy for Democracy and People's Independence. Jakarta: Pariba Foundation.

Webter, (1997), Personal and Institutional Factors in Capacity Building and Institutional Development, Working Paper No. 14, Maastrict, ECDPM.

Prasojo, Eko (2009). Second Reform, Continuing Reformation Reform, Salemba Humanika, Jakarta,

Ratnawati, Tri, (2010). Satu Dasa Warsa Expansion of the Reformation Era: Failure of Regional Autonomy, LIPI Journal, Issue 21, 2010.

Smith. (1985). Decentralization the Terrortial Demension of The State. George Allence Un Win (publisher): London.

Smart, M.S., \& Smart.R.C. (1972), Children Development and Relationship. New York: The Mac Millan Co.

Smith. 1985. Decentralization The Terrortial Demension of The State. George Allence Un Win (publisher): London.

Surbakti, Ramlan, 1992. Understanding Political Science, Jakarta: Gramedia Widia Sarana Indonesia.

Thoha, Miftah. (2015). Government Bureaucracy and Power in Indonesia, Matapena Institute Yogyakarta.

Tryatmoko, Wahyu Mardyanto. (2010). A Decade of Post-New Order Regions Arrangement: Problems and Solutions for Reform. International Seminar Paper 
Page 554-570. ISBN: 978-602-6 988-75-1

Web Jurnal Online: jurnal.unmuhjember.ac.id

By: Suraji; Muhammad Ali Embi

The Regional Expansion Policies and Conflict Resolution of Bureaucratic Administration

In Indonesia's Expansion Regions

XI Percik Salatiga Institute with Theme: What's up with 10 years of Regional Autonomy. 21-22 July 2010.

Martin Laffin, 1997. Understanding Minister-Bureaucrat Relation: Applying MultiTheoritic Approaches in Public Management, dalam Australian Journal of Public Administration, Vol. 56, No.1

The Ministry of Internal Affairs, 2017.

The Regional Expansion Had Referred to Regulation No.23/2004 on Regional Government (amended Regulation No32/2014), Governmental Regulation (PP) Number 78 of 2007 on Procedures of Forming.

Regulation Number 43 in 1999 on State Civil Apparatus (later amended Regulation no.5/2014).

\section{Research Findings and Journals}

Penelitian Petr Blunt, Mark Turner (2005) School of Business and Government, University of Canberra, Australia Tentan Desentralisasi, Demokrasi, dan Pembangunan-Konflik Masyarakat di Kamboja.

Research of Rachael Diprose and Ukoha Ukiwo Centre for Research onInequality, Human Security and Ethnicity (CRISE) Department of International Development, University of Oxford, 2013, entitled "Desentralisasi dan Pengurusan Konflik di Indonesia dan Indonesia Nigeria".

Research result of JK Scool of Government in 2012 on "Politik Rente di Daerah Pembahagian Kes Maluku Utara" which found: First, from study in Maluku Utara.

Research of Indarti Purwaka dkk Fakulti Ilmu Sosial dan Ilmu Politik Universiti Bengkulu, 2010, entitled "Konflik Tapal Batas Daerah Bengkulu Utara dengan Daerah Lebong (Kajian Kesan Pembahagian Wilayah di Wilayah Bengkulu)”.

Rencana Pembangunan Jangka Menengah Daerah Kabupaten Pangandaran ((Regional Medium-term of Development Plan of Pangandaran Regency) year 2016 - 2021

Laporan Kinerja Instansi Pemerintah (Performance Report of Government Institution, or LAKIP) of Pangandaran Regency, year 2017

Rencana Strategis Inspektorat Kabupaten Pangadaran (Strategic Plan of Inspectorate of Pangandaran Regency) 2016-2021

Kompas, January $19^{\text {th }}, 2008$

http://www.undp.or.id/pubs/docs/pemekaran ID.pdf

htttp://id.wikipedia,org/wiki/pemekaran daerah di Indonesia

\section{Law and Regional Regulations}

Undang-undang Nomor 23 Tahun 2004 Tentang Pemerintah Daerah

Undang-unadang Nomor 21 Tahun 2001 Tentang Autonomi Khusus.

Undang Undang Nomor 25 tahun 2009 tentang Pelayanan Awam.

Peraturan Pemerintah Nomor 78 Tahun 2007 Tentang Pembentukan, Pembahagian, Penggabungan, dan Penghapusan Daerah-daerah Otonom. 
Page 554-570. ISBN: 978-602-6 988-75-1

Web Jurnal Online: jurnal.unmuhjember.ac.id

By: Suraji; Muhammad Ali Embi

The Regional Expansion Policies and Conflict Resolution of Bureaucratic Administration

In Indonesia's Expansion Regions

Petunjuk Pelaksanaan Penanganan Pentadbiran Pemberhentian dengan Hak Pensiun

Kakitangan Negeri Sipil Sekertariat Negara Reawam Indonesia, disusun oleh

Sekertariat Negara RI Kepala Biro Organisasi dan Humas.

Lampiran II Peraturan Menpan dan RB No. 31 Tahun 2012 Tentang Petunjuk Teknikal

Penilaian Mandiri Pelaksanaan Pembaharuan Birokrasi Secara Online.

Peraturan Menter Pendayagunaan Peralatan Negara Nomor PER/20/M.PAN/04/2006

Tahun 2006 tentang Pedoman Penyusunan Standar Pelayanan Awam.

Peraturan Menteri Negara Pendayagunaan Peralatan Negara Nomor 13 Tahun 2009

Tentang Pedoman Peningkatan Kualitas Pelayanan AwamDengan Partisipasi

Masyarakat, Kementerian Negara Pendayagunaan Peralatan Negara.

Keputusan Menteri Pendayagunaan Peralatan Negara Nomor 25/KEP/M.PAN/4/ 2002

Tentang Pedoman Pembangunan Budaya Kerja Peralatan Negara.

Keputusan Menteri Pendayagunaan Peralatan Negara dan Pembaharuan Birokrasi Nomor

39 Tahun 2012 tentang Pedoman Pembangunan Budaya Kerja.

Peraturan Bupati Pangandaran No.3/20014 Tentang Organisasi Daerah Daerah Pangandaran.

Perundang-undangan Khusus Papua Nomor 21 Tahun 2001. 